\title{
Efficacy of prothrombin complex concentrates for the emergency reversal of dabigatran-induced anticoagulation
}

\author{
Oliver Grottke ${ }^{1 *}$, James Aisenberg ${ }^{2}$, Richard Bernstein ${ }^{3}$, Patrick Goldstein ${ }^{4}$, Menno V. Huisman ${ }^{5}$, Dara G. Jamieson ${ }^{6}$, \\ Jerrold H. Levy ${ }^{7}$, Charles V. Pollack Jr ${ }^{8}$, Alex C. Spyropoulos ${ }^{9}$, Thorsten Steiner ${ }^{10}$, Gregory J. del Zoppo ${ }^{11}$ \\ and John Eikelboom ${ }^{12}$
}

\begin{abstract}
Dabigatran is effective in decreasing the risk of ischaemic stroke in patients with atrial fibrillation. However, like all anticoagulants, it is associated with a risk of bleeding. In cases of trauma or emergency surgery, emergency reversal of dabigatran-induced anticoagulation may be required. A specific reversal agent for dabigatran, idarucizumab, has been approved by the US Food and Drug Administration. Alternative reversal agents are available, such as prothrombin complex concentrates (PCCs) and activated PCCs (aPCCs). In this review we evaluate the role of PCCS and aPCCs in the reversal of dabigatran anticoagulation and consider which tests are appropriate for monitoring coagulation in this setting. Pre-clinical studies, small clinical studies and case reports indicate that PCCs and aPCCs may be able to reverse dabigatran-induced anticoagulation in a dose-dependent manner. However, dosing based on coagulation parameters can be difficult because available assays may not provide adequate sensitivity and specificity for measuring anticoagulation induced by dabigatran or the countering effects of PCCs/aPCCs. In addition, PCCs or aPCCs can potentially provoke thromboembolic complications. Despite these limitations and the fact that PCCs and aPCCs are not yet licensed for dabigatran reversal, their use appears to be warranted in patients with life-threatening haemorrhage if idarucizumab is not available.
\end{abstract}

Keywords: Anticoagulation, Activated prothrombin complex concentrate, Bleeding, Dabigatran, Prothrombin complex concentrate, Trauma

\section{Background}

For more than 60 years, the only oral anticoagulants available for the prevention of ischaemic stroke in patients with non-valvular atrial fibrillation (AF) have been the vitamin $\mathrm{K}$ antagonists (VKAs), such as warfarin, phenprocoumon and acenocoumarol [1]. However, the need for coagulation monitoring and dose adjustments, as well as concerns about drug-drug or diet-drug interactions and the risk of bleeding, have restricted the use of VKAs for ischaemic stroke prevention in patients with AF $[2,3]$. Several direct oral anticoagulants (DOACs) have been approved for this indication: the oral direct thrombin inhibitor dabigatran, and oral direct factor Xa

\footnotetext{
* Correspondence: ogrottke@ukaachen.de

'Department of Anesthesiology, RWTH Aachen University Hospital,

Pauwelsstrasse 30, 52074 Aachen, Germany

Full list of author information is available at the end of the article
}

inhibitors (e.g. rivaroxaban, apixaban or edoxaban) $[4,5]$. Compared with VKAs, DOACs produce a more predictable anticoagulant effect and can be given in fixed doses without routine coagulation monitoring. The results of randomised controlled trials (RCTs) and observational studies indicate that DOACs are at least as effective as VKAs for stroke prevention in patients with AF, with reduced rates of intracranial bleeding and, at certain doses, a reduction in life-threatening bleeding [6-10].

Dabigatran, the active moiety of dabigatran etexilate, has a rapid onset of action, and the plasma concentration peaks within $0.5-2.0$ hours of administration [11]. This anticoagulant has a half-life of $7-17$ hours [12] and is eliminated predominantly via renal excretion (80\%) [13]. Dabigatran is licensed in many countries for several indications, including: primary prevention of venous thromboembolism (VTE) in patients who have undergone 
elective total hip or knee arthroplasty (150 mg or $220 \mathrm{mg}$ once daily); prevention of ischaemic stroke and systemic embolism in adult patients with non-valvular AF (110 or $150 \mathrm{mg}$ twice daily, except in the USA where 75 and $150 \mathrm{mg}$ twice-daily doses are approved); and treatment of acute deep vein thrombosis (DVT) and pulmonary embolism (110 and $150 \mathrm{mg}$ twice daily, except in the USA where only the $150 \mathrm{mg}$ twice-daily dose is approved) $[14,15]$.

Most episodes of bleeding in patients treated with dabigatran can be managed with supportive measures and by temporarily withholding the drug. However, additional strategies may be needed in patients with life-threatening bleeding and those who require urgent or emergency surgery or other invasive procedures for which haemostasis is necessary. Supportive care is also not sufficient in patients with intracranial bleeding, where outcome may be directly associated with the time needed for coagulation reversal [16].

A specific reversal agent for dabigatran, idarucizumab, has been approved by the US Food and Drug Administration. Animal models and phase I-III clinical data show that idarucizumab achieves predictable, complete and sustained reversal of dabigatran, with the potential for significant reductions in blood loss [17-19]. In an interim analysis of the phase III RE-VERSE AD study [19], involving 90 dabigatran-treated patients with serious bleeding or in need of an urgent surgical procedure, idarucizumab completely reversed the effects of dabigatran within minutes. Idarucizumab appears to be well tolerated, and it has no direct effects on procoagulant or anticoagulant activity $[17,19]$. However, idarucizumab is yet to be approved in many countries and, pending its widespread availability, multiple therapeutic options have been suggested for emergency reversal of dabigatran's anticoagulant effects. These options include prothrombin complex concentrates (PCCs) and activated PCCs (aPCCs), as well as recombinant activated factor VII (rFVIIa) [20-24].

In this article we review pre-clinical and clinical evidence for the use of PCCs and aPCCs to restore haemostasis in dabigatran-treated patients with either haemorrhage or the need for an urgent surgical procedure, and review the role of laboratory coagulation assessments in this setting [20-24].

\section{Mechanism of action of dabigatran}

Dabigatran is a small molecule that binds competitively and selectively to the catalytic site of thrombin $[25,26]$. Since thrombin facilitates coagulation by converting fibrinogen into a fibrin network, dabigatran has the effect of blocking the terminal coagulation cascade (Fig. 1) [27]. Additional effects of thrombin prevented by dabigatran include platelet activation, amplification of coagulation activation (positive feedback mechanism) and inhibition of fibrinolysis [25].

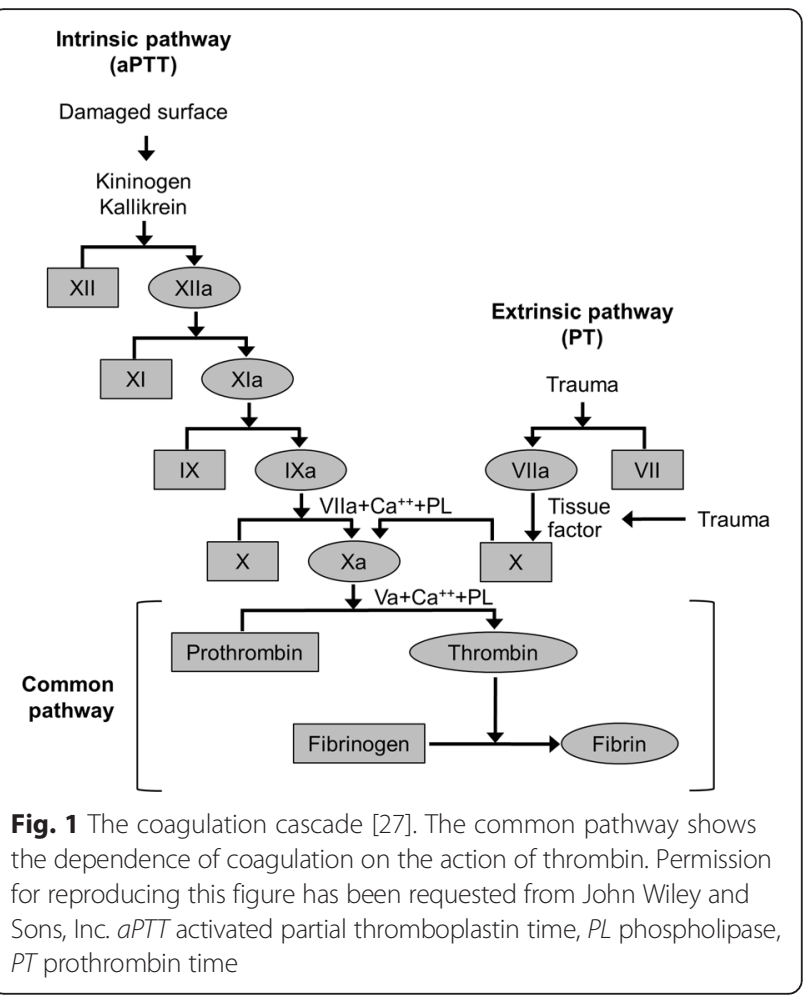

\section{Pre-surgical management of the dabigatran- anticoagulated patient}

Because dabigatran has a short half-life (in patients with normal renal function) and its effects on thrombin are reversible, the general recommendation for dabigatrantreated patients scheduled to receive elective surgery is to discontinue therapy temporarily and wait for the remaining drug to be eliminated naturally. The timing of discontinuation before elective surgery is based on a patient's renal function and risk of bleeding, and the type of surgery planned. In patients with normal renal function, dabigatran should be stopped at least 24 hours before surgery with a standard risk of bleeding; a 48-hour interim is appropriate if the risk of bleeding is high [15]. These time periods increase to 2-3 days and 4 days, respectively, in patients with reduced renal function (creatinine clearance $\geq 30-50 \mathrm{ml} / \mathrm{min}$ ) [28].

\section{General bleeding management of the dabigatran- anticoagulated patient}

Expert and professional society guidelines are available regarding emergency bleeding management in patients receiving dabigatran treatment [28-32]. There are variations in the specifics but the principles are consistent across different guidelines. The general approach to managing nonemergency bleeding complications is similar to that with pre-surgical management, i.e. discontinue dabigatran therapy temporarily and wait for the elimination of dabigatran. In this review, we will focus on major or life-threatening 
bleeding (including intracranial bleeding) and emergency surgery, where a need for more rapid reversal of the effects of dabigatran necessitates a different strategy. Exogenous coagulation factor repletion with PCCs or aPCCs has been suggested as a potential treatment option in these settings [33].

The initial steps of bleeding management algorithms typically consist of local/surgical haemostasis where appropriate, qualitatively assessing anticoagulant activity (e.g. by activated partial thromboplastin time (aPTT)), and general measures such as volume replacement and blood product transfusion. Medical history including anticoagulant intake is integral to the early phase of treatment. In many cases, however, anticoagulation may not be contributing meaningfully to the bleeding and so reversal of dabigatran is not usually a first-line priority. In the RE-VERSE AD study [19], 22 out of 90 enrolled patients did not have prolonged diluted thrombin times (dTTs) due to the natural clearance of dabigatran. Acquired coagulopathy can develop secondary to blood loss, loss and consumption of coagulation factors and haemodilution owing to excessive fluid replacement. This is a major risk factor for progression from initial bleeding to severe haemorrhage. There is some evidence suggesting that 'restrictive' or goal-directed as opposed to 'liberal' fluid resuscitation strategies may reduce morbidity and lengths of hospital stay $[34,35]$. However, other investigations have cast doubt on the benefits of a restrictive approach [36] and, importantly, hypovolaemia can cause acidosis, thereby exacerbating coagulopathy. In the presence of substantial tissue injury and haemorrhagic shock, activation of protein $\mathrm{C}$ and subsequent hyperfibrinolysis may also aggravate coagulopathy [37]. Early intervention with haemostatic therapy (e.g. fibrinogen concentrate, cryoprecipitate, fresh frozen plasma, platelets) may be critical for preventing complex coagulopathies and progression to severe, life-threatening haemorrhage-especially in patients who have bled so that they have acquired coagulopathy in addition to anticoagulant therapy. Multimodal therapy should therefore be administered as early as possible in life-threatening bleeding under dabigatran anticoagulation [38].

\section{Laboratory evaluation of dabigatran concentration}

Although patients taking dabigatran do not need to undergo routine coagulation monitoring, rapid assessment of whether or not the patient is actively anticoagulated is important in an emergency situation. This information can help determine the contribution of anticoagulation to the bleeding, the need for a reversal/repletion strategy and whether an invasive procedure should be delayed $[39,40]$.

A variety of tests have been explored for the detection or quantification of plasma dabigatran activity, but limitations are common. For example, the prothrombin time (PT) and the international normalised ratio (INR) exhibit low sensitivity to anticoagulation with dabigatran, with therapeutic doses having minimal effect; these tests are therefore not recommended [31]. Thrombin-generation assays and viscoelastic testing parameters have also been considered, but thrombin-generation assays are mostly restricted to research settings and viscoelastic testing has not been validated for the monitoring of dabigatran in a clinical setting [40]. The aim of testing for dabigatran activity is often not to provide precise quantification of dabigatran, but simply to detect the presence or absence of drug in plasma. This is particularly important in patients with acute ischaemic stroke, for whom thrombolytic therapy or procedures requiring high-dose antiplatelet agents are being considered. Candidate tests are now described in more detail and are summarised in Table 1.

The aPTT exhibits a non-linear dose response with increasing concentrations of dabigatran, plateauing at higher concentrations [31]. In addition, in some patients taking dabigatran, normal-range aPTT values have been reported when dabigatran is at trough levels [41]. This test is therefore not suitable for precise quantification, particularly at high or low dabigatran concentrations, but can provide an approximate indication of dabigatran levels [42]. The aPTT is readily available and therefore is commonly used to evaluate dabigatran activity or possible drug ingestion; normal aPTT results reduce the likelihood of therapeutic anticoagulation.

The thrombin time (TT) exhibits a very steep, linear dose response with increasing concentrations of dabigatran. This test can be considered excessively sensitive for the detection of dabigatran activity because samples may not clot at dabigatran concentrations above $100 \mathrm{ng} / \mathrm{ml}$, a level within the expected clinical range $[41,43]$. Therefore, the use of this assay for quantifying therapeutic concentrations of dabigatran is limited. However, the TT is a very useful assay to determine the presence of low levels of dabigatran, with TT values within the normal range suggesting the absence of dabigatran.

The TT and aPTT assays are useful tests in the clinical setting and can be used in combination, with the TT detecting the presence or absence of drug and the aPTT providing an approximate indication of the plasma dabigatran concentration. These assays are readily accessible and can provide information rapidly.

Tests that are used principally for research have also been considered for assessing dabigatran anticoagulation. For example, dedicated direct thrombin inhibition assays have a linear relationship over a wide range of plasma dabigatran concentrations [44]. The dTT is one type of direct thrombin inhibition assay, in which plasma is diluted in buffer and then supplemented with normal human plasma; clotting is then initiated with thrombin. 
Table 1 Clinical and research tests available for the assessment of plasma dabigatran concentration

\begin{tabular}{|c|c|c|c|}
\hline Test & $\begin{array}{l}\text { Sensitivity to plasma } \\
\text { dabigatran concentration }\end{array}$ & Availability & Clinical recommendation \\
\hline Thrombin time & $\begin{array}{l}\text { Linear dose response; } \\
\text { oversensitive }\end{array}$ & Widely available & $\begin{array}{l}\text { Recommended for detection of presence or } \\
\text { absence of dabigatran activity }\end{array}$ \\
\hline Activated partial thromboplastin time (aPTT) & Non-linear dose response & Widely available & $\begin{array}{l}\text { Recommended for semi-quantitative estimation } \\
\text { of dabigatran activity; normal aPTT does not } \\
\text { always exclude presence of dabigatran }\end{array}$ \\
\hline Direct thrombin inhibition assays & \multirow{3}{*}{$\begin{array}{l}\text { Linear dose response; } \\
\text { sensitive }\end{array}$} & \multirow{3}{*}{$\begin{array}{l}\text { Usually available in } \\
\text { specialised centres }\end{array}$} & \multirow{3}{*}{$\begin{array}{l}\text { Recommended for measurement of plasma } \\
\text { concentration; ECT usually a local assay because } \\
\text { commercial kits not available; not validated } \\
\text { for dabigatran }\end{array}$} \\
\hline Diluted thrombin time & & & \\
\hline Ecarin clotting time (ECT) & & & \\
\hline $\begin{array}{l}\left.\text { Thromboelastometry (ROTEM }{ }^{\circ}\right) / \\
\text { thrombelastography }\left(\mathrm{TEG}^{\circ}\right) \text { assays } \\
\text { EXTEM/Rapid TEG }\end{array}$ & Sensitive & Limited availability & $\begin{array}{l}\text { Potential measurement of effectiveness of } \\
\text { treatment for dabigatran-induced anticoagulation; } \\
\text { not validated for dabigatran }\end{array}$ \\
\hline Thrombin-generation assays & Sensitive (lag time) & Limited availability & $\begin{array}{l}\text { Potential measurement of effectiveness of } \\
\text { treatment for dabigatran-induced } \\
\text { anticoagulation; not validated for dabigatran }\end{array}$ \\
\hline $\begin{array}{l}\text { Prothrombin time or international } \\
\text { normalised ratio }\end{array}$ & Low sensitivity & Widely available & Not recommended in this setting \\
\hline
\end{tabular}

This methodology compensates for any coagulation factor deficiencies and only the effect of the direct thrombin inhibition is measured [45]. Ecarin tests, representing another type of direct thrombin inhibition assay, are either clotting based (ecarin clotting time (ECT)) or chromogenic (ecarin chromogenic assay (ECA)) [31, 45]. Ecarin is snake venom that directly activates prothrombin to initiate clotting, thereby bypassing upstream coagulation and enabling direct measurement of the influence of the direct thrombin inhibition. Some ECA tests are supplemented with prothrombin to allow targeted direct thrombin inhibition quantification independent of any coagulopathies in the patient sample. In a recent study, the dTT, ECT and ECA all showed linear correlations with dabigatran concentrations over a broad range [41]. Although these tests are widely available, they are not used in all hospitals [46].

The thrombin-generation parameter 'lag time' and, to some extent, the endogenous thrombin potential (ETP) have been shown to correlate with plasma dabigatran concentrations [47]. Recent studies have also shown that therapeutic dabigatran doses have a significant effect on the lag time, ETP and peak height, when measured by the calibrated automated thrombogram (CAT) [48]. However, thrombin-generation tests are time-consuming and their availability is generally limited to research laboratories and centres specialising in haemostasis. Thrombin-generation parameters therefore cannot be recommended for routine evaluation of plasma dabigatran concentration.

Viscoelastic tests, including thromboelastometry (ROTEM ${ }^{\circ}$ ) or thrombelastography (TEG ${ }^{\circ}$ ), can have faster turnaround times than standard laboratory coagulation tests because they are whole-blood based and are often performed in surgical or emergency rooms. This can be beneficial in emergency situations. The ROTEM EXTEM and Rapid TEG (r-TEG) assays measure tissue-factorinitiated extrinsic coagulation and pre-clinical data have shown that they are sensitive to dabigatran [49]. There is anecdotal evidence that dabigatran prolongs the activated clotting time (ACT) in r-TEG, when all other standard coagulation tests were within the normal range [50]. However, neither EXTEM nor r-TEG has been calibrated for measuring dabigatran levels; in many centres these assays are not used routinely and there is currently no clinical evidence supporting the use of these tests for this purpose.

\section{Prothrombin complex concentrates (activated and non-activated)}

If the patient continues to sustain major blood loss after initial intervention with haemostatic therapy, or in the setting of intracranial haemorrhage, treatment algorithms recommend further interventions to counteract the anticoagulant effects of dabigatran (Table 2) [28-30, 32]. These interventions include PCCs and aPCCs.

A number of PCCs are commercially available. Detailed analysis of constituent differences between these products has been published previously [51]. All PCCs contain the vitamin K-dependent factors II, IX and X, and are standardised according to their factor IX content. In addition, they contain differing amounts of factor VII; products with low or high quantities of factor VII are known as three-factor or four-factor PCCs, respectively. Some PCCs also contain anticoagulation proteins such as protein $\mathrm{C}$, protein S, protein Z, antithrombin and heparin. Furthermore, aPCCs are available which contain non-activated factors II, IX and X, and activated factor VII.

VKAs (e.g. warfarin) produce their anticoagulant effects by inhibiting the synthesis of vitamin K-dependent 
Table 2 Recommendations and algorithms for the management of bleeding patients with dabigatran-induced anticoagulation

\begin{tabular}{|c|c|c|c|}
\hline Reference & Mild bleeding & Moderate-to-severe bleeding & Life-threatening bleeding or intracranial haemorrhage \\
\hline \multirow[t]{5}{*}{ Weitz et al., 2012 [32] } & \multirow{5}{*}{$\begin{array}{l}\text { Discontinue treatment } \\
\text { until bleeding resolves }\end{array}$} & Sequential treatment: & aPCC (50 IU/kg) \\
\hline & & (1) PCC (40 IU/kg) & \multirow[t]{4}{*}{ If unavailable, give PCC (40 IU/kg) or rFVIla $(90$ mg/kg) } \\
\hline & & (2) aPCC (50 IU/kg) & \\
\hline & & 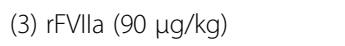 & \\
\hline & & $\begin{array}{l}\text { (4) Haemodialysis for } 6-8 \mathrm{~h} \\
\text { or charcoal filtration }\end{array}$ & \\
\hline \multirow[t]{3}{*}{ Faraoni et al., 2015 [29] } & \multirow[t]{3}{*}{ No recommendation given } & \multirow[t]{3}{*}{ No recommendation given } & (1) Monitor blood loss and perform coagulation assays \\
\hline & & & $\begin{array}{l}\text { (2) Standard resuscitation with fluid therapy, tranexamic } \\
\text { acid }(1 \mathrm{~g}), \mathrm{RBCs} \text { and massive transfusion protocol }\end{array}$ \\
\hline & & & $\begin{array}{l}\text { (3) Four-factor PCC (25-50 IU/kg), aPCC } \\
\text { (FEIBA; 30-50 IU/kg) }\end{array}$ \\
\hline \multirow[t]{8}{*}{ EHRA guidelines [30] } & Maintain diuresis & \multirow{8}{*}{$\begin{array}{l}\text { Same recommendation } \\
\text { as for mild bleeding }\end{array}$} & \multirow{8}{*}{$\begin{array}{l}\text { PCC } 50 \mathrm{U} / \mathrm{kg} \text { (additional } 25 \mathrm{U} / \mathrm{kg} \text { if clinically needed) } \\
\text { aPCC } 50 \mathrm{U} / \mathrm{kg} \text { (maximum } 200 \mathrm{U} / \mathrm{kg} / \text { day) } \\
\mathrm{rFVlla}(90 \mathrm{mg} / \mathrm{kg} \text { ) } \\
\text { Idarucizumab } 5 \mathrm{~g} \text { intravenously }\end{array}$} \\
\hline & Local haemostatic measures & & \\
\hline & Fluid replacement & & \\
\hline & RBC substitution if necessary & & \\
\hline & $\begin{array}{l}\text { Platelet substitution } \\
\text { if necessary }\end{array}$ & & \\
\hline & $\begin{array}{l}\text { FFP as plasma expander } \\
\text { (not as reversal agent) }\end{array}$ & & \\
\hline & $\begin{array}{l}\text { Consider tranexamic } \\
\text { acid or desmopressin }\end{array}$ & & \\
\hline & Consider dialysis & & \\
\hline ESA guidelines [28] & No recommendation given & No recommendation given & $\begin{array}{l}\text { PCC, aPCC or rFVIla may be used as non-specific } \\
\text { antagonists }\end{array}$ \\
\hline
\end{tabular}

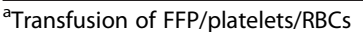

aPCC activated prothrombin complex concentrate, EHRA European Heart Rhythm Association, ESA European Society of Anaesthesiology, FFP fresh frozen plasma, $P C C$ prothrombin complex concentrate, $R B C$ red blood cell, $r F V I l a$, recombinant activated factor VII, FEIBA, factor eight inhibitor bypassing activity

coagulation factors II, VII, IX and X. In patients with life-threatening bleeding, rapid replacement of these coagulation factors is required and therefore PCCs are a reasonable option. Both three-factor and four-factor PCCs have been investigated for the reversal of VKAs; four-factor PCCs are more commonly used, because three-factor PCCs do not provide adequate reductions in INR owing to the low levels of factor VII [52]. The first four-factor PCC was approved in the United States in 2013, specifically for this purpose [53]. Nevertheless, in VKA-associated bleeding, data for PCCs are based principally on laboratory rather than clinical endpoints, meaning that the evidence may be considered not to be at the highest level.

For the treatment of dabigatran-induced anticoagulation, neither PCCs nor aPCCs act as specific reversal agents for dabigatran or any other DOAC. Instead, they raise levels of the vitamin K-dependent coagulation factors, notably prothrombin, and thrombin generation is consequently increased. In the case of dabigatran, the plasma concentration of thrombin is increased to a stoichiometric excess vs the drug, and therefore levels of free (unbound) dabigatran and the antithrombotic effect of the drug are minimised. Data from pre-clinical and clinical studies of PCCs and aPCCs for reversal of dabigatran (see later sections) are consistent with this mechanism of action.

Although a number of suitable tests for the monitoring of plasma dabigatran concentration have been identified, it does not necessarily follow that these are the most appropriate tests for monitoring the reversal of dabigatraninduced anticoagulation by PCCs or aPCCs. For example, the aPTT may be useful in providing an approximate indication of dabigatran levels, but appears to be insensitive to the reversal effects of PCCs and aPCCs [49]. There is some evidence to suggest that the EXTEM assay parameters clotting time (CT) and clot formation time (CFT) are sensitive to the effects of PCCs and aPCCs on dabigatran anticoagulation; therefore, these parameters may potentially provide a means of monitoring dabigatran reversal, although clinical studies are warranted [49].

\section{Efficacy of PCCs and aPCCs for treating dabigatran-induced anticoagulation}

The efficacy of PCCs/aPCCs to treat dabigatran-induced anticoagulation has been investigated in several pre-clinical 
studies, clinical studies and case reports; these are summarised in this section and in Tables 3, 4 and 5 .

\section{Pre-clinical animal studies}

A mouse model of intracerebral haemorrhage was developed to test the efficacy of PCC in preventing haematoma growth associated with dabigatran treatment [54]. Compared with controls, dabigatran etexilate $(9.0 \mathrm{mg} /$ $\mathrm{kg} ; n=391)$ significantly increased the haematoma volume $\left(17.0 \mathrm{~mm}^{3}\right.$ vs $\left.11.9 \mathrm{~mm}^{3} ; p=<0.05\right)$. The administration of $100 \mathrm{U} / \mathrm{kg}$ PCC, 30 minutes after the induction of intracerebral haemorrhage, effectively prevented dabigatran from increasing the haematoma volume $\left(11.7 \mathrm{~mm}^{3}\right.$; $p<0.05$ vs dabigatran alone) and significantly reduced 24hour mortality ( $4 \%$ vs $30 \%$ in mice receiving dabigatran alone; $p<0.05)[54]$.

Another study assessed the efficacy of PCC in the treatment of dabigatran-induced anticoagulation in a rabbit model [55]. Rabbits were given $0.4 \mathrm{mg} / \mathrm{kg}$ dabigatran $(n=$ $20)$ and, 5 minutes later, PCC (20, 35 or $50 \mathrm{IU} / \mathrm{kg})$ or placebo. After another 5 minutes, a standardised kidney incision injury was created. Compared with placebo, PCC produced a dose-dependent reduction in blood loss and acceleration in haemostasis.

A more recent study in rabbits assessed the efficacy of PCC for the treatment of dabigatran-induced anticoagulation, using different doses of both drugs [56]. Dabigatran was administered to anaesthetised rabbits as a $0,75,200$ or $450 \mu \mathrm{g} / \mathrm{kg}$ bolus dose, followed by continuous infusion to maintain the post-bolus plasma dabigatran level. After 15 minutes, animals were given PCC doses of 0,50 or $300 \mathrm{IU} / \mathrm{kg}$ and subjected to standardised kidney injury. The increase in blood loss induced by dabigatran was effectively attenuated by PCC. In addition, the thromboembolic risk associated with PCC (measured by histopathological examination of lung, kidney, heart and brain tissue) was reduced by the presence of dabigatran [56].

Both PCC and aPCC have been shown to be effective in treating the anticoagulant effect of dabigatran ex vivo in a porcine trauma model [49]. Dabigatran etexilate was given to animals $(n=5)$ orally for 3 days prior to surgery and intravenously on day 4 to achieve a supratherapeutic plasma dabigatran concentration (mean $1423 \mathrm{ng} / \mathrm{ml}$ ). Following standardised blunt liver injury, blood samples were taken and PCC or aPCC (concentrations equivalent to doses of 30 and $60 \mathrm{U} / \mathrm{kg}$ ) was added ex vivo. Both PCC and aPCC diminished the effects of dabigatran and trauma-induced coagulopathy. No differences were observed between PCC and aPCC [49].

In a similar porcine model of trauma with dabigatran anticoagulation, some animals received tranexamic acid $(20 \mathrm{mg} / \mathrm{kg}$ ) and fibrinogen concentrate $(80 \mathrm{mg} / \mathrm{kg})$ following trauma, before ex-vivo administration of PCC [18]. PCC administration effectively reduced dabigatran-induced anticoagulation, as shown by significant decreases in PT, EXTEM CT and EXTEM CFT. PCC also yielded additional coagulation improvements among animals treated with tranexamic acid and fibrinogen concentrate. The exvivo study design precluded assessment of the effects of PCC/aPCC on blood loss; consequently, two additional studies were performed using the same model of injury, with in-vivo administration of PCC or aPCC.

In the first of these studies, animals receiving dabigatran and polytrauma were randomly assigned to receive saline control or aPCC (25 or $50 \mathrm{IU} / \mathrm{kg}$ ) [57]. Blood loss was not significantly different between animals in the control and $25 \mathrm{IU} / \mathrm{kg}$ aPCC groups $(3807 \mathrm{ml}$ and $3690 \mathrm{ml}$, respectively); however, $50 \mathrm{IU} / \mathrm{kg}$ aPCC was associated with blood loss of $1639 \mathrm{ml}$, a statistically significant reduction vs control and $25 \mathrm{IU} / \mathrm{kg}$ aPCC $(p<0.0001)$ [57]. aPCC was shown to produce improvements in $\mathrm{PT}$, in $\mathrm{CT}$ and CFT in the EXTEM and INTEM assays and in thrombingeneration peak height and ETP; but not in aPTT or ACT.

Three doses of PCC $(25,50$ or $100 \mathrm{IU} / \mathrm{kg}$ (PCC25, PCC50 or PCC100)) were compared with saline control in the second study [58]. Total blood loss was significantly lower in animals receiving the higher doses of PCC (PCC50 and PCC100: $1749 \mathrm{ml}$ and $1692 \mathrm{ml}$, respectively) than in the control and PCC25 groups $(3855 \mathrm{ml}$ and $3588 \mathrm{ml}$, respectively). All doses of PCC improved the coagulation parameters INTEM CT, EXTEM CT and EXTEM CFT vs controls. In addition, PCC50 and PCC100 produced sustained increases in ETP [58]. Overall, this study showed that PCC25 produced similar outcomes to control, with only PCC50 and PCC100 reducing blood loss, but that PCC100 is associated with a procoagulant state. The study also confirmed the low sensitivity of certain coagulation parameters (e.g. ACT, aPTT, thrombin-generation lag time) to the effects of PCC on dabigatran anticoagulation.

In summary, these pre-clinical studies have demonstrated that sufficient doses of both PCC and aPCC (50 IU/ $\mathrm{kg}$ ) can successfully reverse the effects of dabigatran-induced anticoagulation in the pre-clinical setting, as shown by improvements in coagulation parameters, blood loss and mortality. The lack of effectiveness of lower doses may be explained by insufficient increases in thrombin generation. These studies do not show any significant differences between PCC and aPCC in the reduction of bleeding or the degree of thrombin generation. In addition, the lack of sensitivity of the aPTT test emphasises the importance of selecting an appropriate coagulation test for monitoring dabigatran reversal by PCCs or aPCCs [18, 49]. It is important to note that in the porcine studies the examined doses of PCC and aPCC were sufficient to control bleeding under high dabigatran concentrations; lower doses would almost certainly be adequate with lower, therapeutic plasma concentrations of dabigatran. 
Table 3 Pre-clinical studies investigating the use of PCCs and aPCCs to reverse dabigatran-induced anticoagulation

\begin{tabular}{|c|c|c|c|c|c|}
\hline \multirow[t]{2}{*}{ Reference } & \multirow[t]{2}{*}{ Study design } & \multicolumn{2}{|l|}{ Dose } & \multirow[t]{2}{*}{ Main results } & \multirow[t]{2}{*}{ Conclusion } \\
\hline & & Dabigatran (mg/kg) & PCC (IU/kg) & & \\
\hline \multirow[t]{6}{*}{ Zhou et al., 2011 [54] } & \multirow{6}{*}{$\begin{array}{l}\text { Murine intracerebral } \\
\text { haemorrhage model }\end{array}$} & \multirow[t]{6}{*}{9.0} & \multirow[t]{6}{*}{100} & Haematoma volume: & \multirow{6}{*}{$\begin{array}{l}\text { PCC effectively prevented haematoma growth } \\
\text { and significantly reduced } 24-\mathrm{h} \text { mortality }\end{array}$} \\
\hline & & & & Post-dabigatran: $17.0 \pm 4.1 \mathrm{~mm}^{3}$ & \\
\hline & & & & Post-PCC: $11.7 \pm 3.0 \mathrm{~mm}^{3}$ & \\
\hline & & & & Mortality: & \\
\hline & & & & Control animals: 30 \% & \\
\hline & & & & PCC-treated mice: 4 \% & \\
\hline \multirow[t]{6}{*}{ Pragst et al., 2012 [55] } & \multirow{6}{*}{$\begin{array}{l}\text { Leporine standardised } \\
\text { kidney injury model }\end{array}$} & \multirow[t]{6}{*}{0.4} & \multirow[t]{6}{*}{20,35 or 50} & Blood loss: & \multirow{6}{*}{$\begin{array}{l}\text { PCC resulted in a dose-dependent reduction } \\
\text { in blood loss and acceleration in haemostasis. } \\
\text { At the highest dose, blood loss was normalised } \\
\text { in all animals. All doses of PCC successfully } \\
\text { treated dabigatran-induced anticoagulation } \\
\text { at plasma concentrations similar to those seen } \\
\text { in patients receiving dabigatran }\end{array}$} \\
\hline & & & & Control: $1.0-7.2 \mathrm{ml}$ & \\
\hline & & & & Post-dabigatran: mean 29 ml & \\
\hline & & & & $\begin{array}{l}\text { Post-PCC: decreased by } \\
5.44 \mathrm{ml} \text { per } 10 \mathrm{IU} / \mathrm{kg} \text { PCC }\end{array}$ & \\
\hline & & & & No change in aPTT & \\
\hline & & & & $\begin{array}{l}\text { PT shortened by } 0.335 \mathrm{~s} \\
\text { per } 10 \mathrm{IU} / \mathrm{kg} \text { PCC }\end{array}$ & \\
\hline \multirow[t]{5}{*}{ Herzog et al., 2014 [56] } & \multirow{5}{*}{$\begin{array}{l}\text { Leporine arterial venous } \\
\text { shunt model }\end{array}$} & \multirow[t]{5}{*}{$0,0.075,0.2,0.45$} & \multirow[t]{5}{*}{0,5 or 300} & Bleeding time: & \multirow{5}{*}{$\begin{array}{l}\text { Dabigatran-induced bleeding was effectively } \\
\text { reversed by PCC. The thromboembolic risk } \\
\text { associated with PCC administration appeared } \\
\text { to be reduced due to the persistence of } \\
\text { dabigatran in the plasma }\end{array}$} \\
\hline & & & & $\begin{array}{l}\text { Increasing PCC doses shortened } \\
\text { time to haemostasis for rabbits } \\
\text { treated with } 0.2 \mathrm{mg} / \mathrm{kg} \text { dabigatran }\end{array}$ & \\
\hline & & & & $\begin{array}{l}\text { No dose of PCC could reverse } \\
\text { the effects of } 0.45 \mathrm{mg} / \mathrm{kg} \\
\text { dabigatran on time to haemostasis }\end{array}$ & \\
\hline & & & & Thrombosis: & \\
\hline & & & & $\begin{array}{l}\text { The frequency of pulmonary } \\
\text { thrombi decreased progressively } \\
\text { with increasing concomitant } \\
\text { dabigatran dose }\end{array}$ & \\
\hline \multirow[t]{4}{*}{ Grottke et al., 2014 [49] } & \multirow[t]{4}{*}{ Porcine liver trauma model } & \multirow{4}{*}{$\begin{array}{l}30 \text { (daily oral dose) then } \\
\text { intravenous infusion to } \\
\text { reach supratherapeutic } \\
\text { plasma concentration }\end{array}$} & PCC: & PCC: & \multirow{4}{*}{$\begin{array}{l}\text { Both PCC and aPCC diminished the effects } \\
\text { of dabigatran, restoring ROTEM parameters } \\
\text { and PT to } 80-90 \% \text { of baseline }\end{array}$} \\
\hline & & & 30 or 60 & No effect on aPTT & \\
\hline & & & aPCC: & aPCC: & \\
\hline & & & 30 or 60 & No effect on aPTT & \\
\hline
\end{tabular}


Table 3 Pre-clinical studies investigating the use of PCCs and aPCCs to reverse dabigatran-induced anticoagulation (Continued)

\begin{tabular}{|c|c|c|c|c|c|}
\hline \multirow[t]{2}{*}{ Honickel et al., 2015 [57] } & \multirow[t]{2}{*}{ Porcine polytrauma model } & \multirow{2}{*}{$\begin{array}{l}30 \text { (daily oral dose) then } \\
\text { intravenous infusion to } \\
\text { reach supratherapeutic } \\
\text { plasma concentration }\end{array}$} & aPCC: & \multirow{2}{*}{$\begin{array}{l}50 \mathrm{IU} / \mathrm{kg} \text { aPCC associated with } \\
\text { significant reduction in blood } \\
\text { loss vs placebo group and } \\
\text { those treated with } 25 \mathrm{IU} / \mathrm{kg}\end{array}$} & $\begin{array}{l}\text { aPCC (50 IU/ } / \mathrm{kg}) \text { is effective in reducing } \\
\text { blood loss in anticoagulated pigs }\end{array}$ \\
\hline & & & 25 or 50 & & $\begin{array}{l}\text { Lower-dose aPCC ( } 25 \mathrm{IU} / \mathrm{kg} \text { ) had an initial } \\
\text { effect that was not sustained, suggesting } \\
\text { stoichiometric excess of prothrombin vs } \\
\text { dabigatran may be required }\end{array}$ \\
\hline Honickel et al., 2015 [18] & Porcine polytrauma model & $\begin{array}{l}30 \text { (daily oral dose) then } \\
\text { intravenous infusion to } \\
\text { reach supratherapeutic } \\
\text { plasma concentration }\end{array}$ & 30 or 60 & Significant decreases in PT, CT and CFT & $\begin{array}{l}\text { Three-factor and four-factor PCCs are } \\
\text { similarly effective for dabigatran reversal }\end{array}$ \\
\hline \multirow[t]{3}{*}{ Honickel et al., 2015 [58] } & \multirow[t]{3}{*}{ Porcine polytrauma model } & \multirow{3}{*}{$\begin{array}{l}30 \text { (daily oral dose) then } \\
\text { intravenous infusion to } \\
\text { reach supratherapeutic } \\
\text { plasma concentration }\end{array}$} & \multirow[t]{3}{*}{25,50 or 100} & \multirow{2}{*}{$\begin{array}{l}50 \text { and } 100 \mathrm{IU} / \mathrm{kg} \text { PCC associated with } \\
\text { significant reductions in blood loss vs } \\
\text { placebo group and those treated } \\
\text { with } 25 \mathrm{IU} / \mathrm{kg}\end{array}$} & $\begin{array}{l}\text { PCC can be effective in reducing blood } \\
\text { loss in anticoagulated pigs }\end{array}$ \\
\hline & & & & & High doses may induce a procoagulant state \\
\hline & & & & $\begin{array}{l}\text { High-dose PCC (100 IU/kg) led to } \\
\text { overcorrection of thrombin generation }\end{array}$ & Low doses may be ineffective \\
\hline
\end{tabular}

aPCC activated prothrombin complex concentrate, aPTT activated partial prothrombin time, CFT clot formation time, CT clotting time, $P C C$ prothrombin complex concentrate, $P T$ prothrombin time 
Table 4 Clinical studies investigating the use of PCCs and aPCCs to reverse dabigatran-induced anticoagulation

\begin{tabular}{|c|c|c|c|c|c|}
\hline \multirow[t]{2}{*}{ Reference } & \multirow[t]{2}{*}{ Study design } & \multicolumn{2}{|l|}{ Dose } & \multirow[t]{2}{*}{ Main results } & \multirow[t]{2}{*}{ Conclusion } \\
\hline & & Dabigatran (mg) & PCC (IU/kg) & & \\
\hline Eerenberg et al., 2011 [59] & $\begin{array}{l}\text { Randomised, placebo-controlled crossover } \\
\text { (study included rivaroxaban and dabigatran) }\end{array}$ & 150 & $\begin{array}{l}50 \text { (administered to } \\
\text { healthy volunteers) }\end{array}$ & $\begin{array}{l}50 \mathrm{IU} / \mathrm{kg} \text { PCC did not correct aPTT, } \\
\text { thrombin-generation lag time, } \mathrm{TT} \text { or ECT }\end{array}$ & $\begin{array}{l}\text { PCC did not neutralise the anticoagulant } \\
\text { effect of dabigatran }\end{array}$ \\
\hline \multirow[t]{2}{*}{ Marlu et al., 2012 [60] } & $\begin{array}{l}\text { Ex vivo, randomised crossover (study } \\
\text { included rivaroxaban and dabigatran) }\end{array}$ & 150 & $\begin{array}{l}\text { PCC (in vitro): } \\
12.5,25 \text { or } 50 \\
\text { aPCC (in vitro): } \\
20,40 \text { or } 80\end{array}$ & $\begin{array}{l}\text { PCC restored changes in ETP at all } \\
\text { three doses }\end{array}$ & $\begin{array}{l}\text { Some non-specific reversal agents appear } \\
\text { able to reverse the anticoagulant activity } \\
\text { of dabigatran }\end{array}$ \\
\hline & & & & $\begin{array}{l}\text { aPCC corrected both ETP and lag time at } \\
\text { doses of } 40 \text { and } 80 \mathrm{U} / \mathrm{kg} \text { but not } 20 \mathrm{U} / \mathrm{kg}\end{array}$ & \\
\hline \multirow[t]{3}{*}{ Herrmann et al., 2014 [48] } & $\begin{array}{l}\text { Ex vivo, cohort study of patients receiving } \\
\text { dabigatran for non-valvular atrial fibrillation }\end{array}$ & 150 & $\begin{array}{l}\text { PCC (in vitro): } \\
500 \mathrm{mU} / \mathrm{ml} \\
\text { aPCC (in vitro): } \\
500 \mathrm{mU} / \mathrm{ml}\end{array}$ & $\begin{array}{l}\text { Dabigatran prolonged aPTT, PT, TT, } \\
\text { dynamic parameters of TEG }{ }^{\circ} \text { and ROTEM } \\
\text { and thrombin-generation lag time; it also } \\
\text { reduced ETP and thrombin-generation } \\
\text { peak height }\end{array}$ & $\begin{array}{l}\text { Some non-specific reversal agents appear } \\
\text { able to reverse the anticoagulant activity } \\
\text { of dabigatran }\end{array}$ \\
\hline & & & & All parameters ameliorated by aPCC & \\
\hline & & & & $\begin{array}{l}\text { All parameters except PT ameliorated } \\
\text { by PCC }\end{array}$ & \\
\hline
\end{tabular}

aPCC activated prothrombin complex concentrate, aPTT activated partial prothrombin time, ECT ecarin clotting time, ETP endogenous thrombin potential, $P C C$ prothrombin complex concentrate, $P T$ prothrombin time, $\pi$ thrombin time 
Table 5 Case studies investigating the use of PCCs and aPCCs to reverse dabigatran-induced anticoagulation

\begin{tabular}{|c|c|c|c|c|c|}
\hline Study & Patient & Dabigatran dose & Case presentation & Treatment & Results \\
\hline \multirow{2}{*}{$\begin{array}{l}\text { Dumkow et al., } \\
2012 \text { [23] }\end{array}$} & \multirow{2}{*}{$\begin{array}{l}85 \text {-year-old male } \\
\text { with hypertension }\end{array}$} & \multirow[t]{2}{*}{150 mg twice daily } & \multirow{2}{*}{$\begin{array}{l}\text { Acute liver failure, acute kidney injury and } \\
\text { anaemia, with upper Gl bleeding from an ulcer }\end{array}$} & 2000 U PCC & \multirow[t]{2}{*}{ Haemoglobin concentration stabilised and bleeding ceased } \\
\hline & & & & 16 U FFP & \\
\hline \multirow{5}{*}{$\begin{array}{l}\text { Weitz et al., } \\
2012[32]\end{array}$} & \multirow{5}{*}{$\begin{array}{l}\text { 78-year-old male with AF, } \\
\text { hypertension and a history } \\
\text { of ischaemic stroke }\end{array}$} & \multirow[t]{5}{*}{150 mg twice daily } & Haematemesis and melena & $8 \cup \mathrm{RBCs}$ & Blood loss was promptly reduced and the patient was stabilised \\
\hline & & & $\mathrm{Hb} 5.9 \mathrm{~g} / \mathrm{dl}$ & $12 \mathrm{U}$ platelets & \multirow{4}{*}{$\begin{array}{l}\text { Patient discharged on reduced dabigatran dose } \\
\text { (75 mg twice daily) }\end{array}$} \\
\hline & & & Creatinine clearance $26 \mathrm{ml} / \mathrm{min}$ & $8 \cup$ cryoprecipitate & \\
\hline & & & aPTT $83 \mathrm{~s}$ & $40 \mathrm{U} / \mathrm{kg}$ PCC & \\
\hline & & & $\Pi>150 \mathrm{~s}$ & & \\
\hline \multirow{4}{*}{$\begin{array}{l}\text { Javedani et al., } \\
2013 \text { [46] }\end{array}$} & \multirow{4}{*}{$\begin{array}{l}\text { 54-year-old male with AF } \\
\text { and hypertension }\end{array}$} & \multirow[t]{4}{*}{150 mg twice daily } & Acute ischaemic stroke & 4520 mg PCC & \multirow{4}{*}{$\begin{array}{l}\text { Coagulation parameters measured post PCC administration: } \\
\text { aPTT } 28.5 \mathrm{~s} \\
\text { INR } 0.82 \\
\text { Patient was discharged after } 7 \text { days on aspirin and warfarin }\end{array}$} \\
\hline & & & Creatinine $1.0 \mathrm{mg} / \mathrm{dl}$ & $1 \mathrm{mg} \mathrm{rFVlla}$ & \\
\hline & & & aPTT $30.3 \mathrm{~s}$ & & \\
\hline & & & INR 1.25 & & \\
\hline \multirow{14}{*}{$\begin{array}{l}\text { Schulman et al., } \\
2014 \text { [61] }\end{array}$} & \multirow{4}{*}{ 84-year-old male with AF } & \multirow{4}{*}{$\begin{array}{l}110 \text { mg (unknown } \\
\text { frequency) }\end{array}$} & Subdural haematoma following a fall & \multirow[t]{4}{*}{$50 \mathrm{U} / \mathrm{kg}$ aPCC } & No immediate change in coagulation profile \\
\hline & & & $\pi 127 \mathrm{~s}$ & & Thrombin time normalised after 3 days \\
\hline & & & aPTT $46 \mathrm{~s}$ & & Bleeding resolved \\
\hline & & & INR 1.2 & & $\begin{array}{l}\text { Patient discharged on day } 4 \text { with complete resolution } \\
\text { of weakness }\end{array}$ \\
\hline & \multirow[t]{4}{*}{$\begin{array}{l}\text { 81-year-old female with AF } \\
\text { and hypertension }\end{array}$} & \multirow[t]{4}{*}{$\begin{array}{l}110 \text { mg (unknown } \\
\text { frequency) }\end{array}$} & \multirow{4}{*}{$\begin{array}{l}\text { CT scan identified haemorrhage in left basal ganglia } \\
\text { aPTT } 48 \mathrm{~s} \\
T T>150 \mathrm{~s}\end{array}$} & \multirow[t]{4}{*}{$42 \mathrm{U} / \mathrm{kg}$ aPCC } & $\begin{array}{l}\text { Repeat imaging after } 3 \text { days showed slight increase in } \\
\text { haematoma size }\end{array}$ \\
\hline & & & & & Speech normalised on day of admission \\
\hline & & & & & Motor function required 2 months rehabilitation \\
\hline & & & & & $\begin{array}{l}\text { Normal mobility and strength but slight right-sided } \\
\text { numbness after } 13 \text { weeks }\end{array}$ \\
\hline & \multirow{3}{*}{$\begin{array}{l}\text { 85-year-old female with AF, } \\
\text { hypertension, dyslipidaemia, } \\
\text { chronic kidney disease and } \\
\text { previous myocardial infarction }\end{array}$} & \multirow[t]{3}{*}{75 mg twice daily } & Undergoing insertion of dual-chamber pacemaker & \multirow[t]{3}{*}{$100 \mathrm{U} / \mathrm{kg}$ aPCC } & \multirow{3}{*}{$\begin{array}{l}\text { Bleeding ceased but thrombin time remained } \\
\text { immeasurable for } 3 \text { days }\end{array}$} \\
\hline & & & aPTT 65 s & & \\
\hline & & & Creatinine clearance $27 \mathrm{ml} / \mathrm{min}$ & & \\
\hline & \multirow[t]{3}{*}{ 83-year-old female with AF } & \multirow[t]{3}{*}{110 mg twice daily } & Admitted to hospital with upper Gl bleeding & $50 \mathrm{U} / \mathrm{kg}$ aPCC & \multirow[t]{3}{*}{ Clinical condition stabilised following administration of PCC } \\
\hline & & & $\mathrm{Hb} 99 \mathrm{~g} / \mathrm{l}$ & $3 \cup \mathrm{RBCs}$ & \\
\hline & & & Creatinine clearance $24 \mathrm{ml} / \mathrm{min}$ & & \\
\hline \multirow{4}{*}{$\begin{array}{l}\text { Masotti et al., } \\
2015 \text { [62] }\end{array}$} & \multirow[t]{4}{*}{ 93-year-old female with AF } & \multirow[t]{4}{*}{110 mg twice daily } & Major bleeding from Gl tract & $25 \mathrm{U} / \mathrm{kg} \mathrm{PCC}$ & Bleeding ceased, but no improvement in coagulation \\
\hline & & & aPTT $89 \mathrm{~s}$ & & \\
\hline & & & PT $21 \%$ & Tranexamic acid & No more re-bleeding occurred \\
\hline & & & & & $\begin{array}{l}\text { Coagulation parameters normalised after } 6 \text { days } \\
\text { (aPTT } 28 \text { s, PT } 90 \% \text { ) and patient was discharged }\end{array}$ \\
\hline
\end{tabular}

AF atrial fibrillation, aPCC activated prothrombin complex concentrate, aPTT activated partial prothrombin time, FFP fresh frozen plasma, GI gastrointestinal, $H b$ haemoglobin, INR international normalised ratio, $P C C$ prothrombin complex concentrate, $P T$ prothrombin time, $R B C$ red blood cell, $r$ FVIla recombinant activated factor VII, $\Pi T$ thrombin time 


\section{Clinical studies: healthy volunteers}

The first study to assess PCCs for the treatment of dabigatran-induced anticoagulation in humans was a randomised, placebo-controlled crossover study [59]. Healthy male volunteers $(n=12)$ were given either $20 \mathrm{mg}$ rivaroxaban or $150 \mathrm{mg}$ dabigatran twice daily, followed by $50 \mathrm{IU} /$ $\mathrm{kg}$ PCC or saline. Following a suitable washout period, study participants were switched to the other anticoagulant. The coagulation tests aPTT, ETP, lag time, TT and ECT were performed to measure the effects of PCC on the anticoagulation induced by dabigatran. Dabigatran prolonged the aPTT $(p<0.001)$, thrombin-generation lag time $(p<0.001)$, TT and ECT $(p=0.002)$ in all subjects. The $50 \mathrm{IU} / \mathrm{kg}$ dose of PCC was not sufficient to normalise any of these parameters in healthy volunteers [59]. This result is attributable to the use of endpoints that are not sensitive to PCC reversal of dabigatran [49]; also, there may be differences between healthy volunteers without coagulopathy and clinical patients in whom emergency dabigatran reversal is needed.

In a randomised, crossover, ex-vivo study, 10 healthy male subjects were randomised to receive one oral dose of either dabigatran (150 mg twice daily) or rivaroxaban (20 mg daily) [60]. After a 2-week washout period, each patient received the other anticoagulant. In dabigatrantreated patients, PCC added to blood samples in vitro effectively reversed dabigatran-induced changes in the ETP at all three doses (12.5, 25 and $50 \mathrm{IU} / \mathrm{kg})$; aPCC was able to correct both the ETP and thrombin-generation lag time at doses of 40-80 U/kg [60].

\section{Clinical studies: patients}

In 17 patients receiving $150 \mathrm{mg}$ dabigatran twice daily for AF following hip or knee arthroplasty, plasma samples were taken to characterise the anticoagulant effect [48]. In addition, the effects of ex-vivo addition of PCCs and aPCCs were investigated using blood samples. Dabigatran administration significantly prolonged a number of laboratory parameters, including the PT, aPTT and TT. In addition, the TEG ${ }^{\circ}$ parameters of reaction time and alpha angle and the ROTEM parameters INTEM CFT and EXTEM CFT were all significantly increased. Assessment of thrombin generation using a CAT (Thrombinoscope BV, Maastricht, the Netherlands) showed that the lag time was increased and ETP was decreased. Ex-vivo addition of $500 \mathrm{mU} / \mathrm{ml}$ PCC significantly ameliorated all parameters with the exception of the PT, and addition of $500 \mathrm{mU} / \mathrm{ml}$ aPCC (FEIBA) ameliorated all parameters [48].

\section{Case reports}

Several case reports assessing the efficacy of PCCs and aPCCs for treatment of bleeding associated with dabigatran-induced anticoagulation have been published. Case-report outcomes constitute low-quality data and cannot be considered conclusive because of the small numbers of patients and variations in aspects such as type of bleeding, doses of PCC/aPCC and co-morbidities of the patients. In addition, individual patients are not usually treated with PCC or aPCC alone, so clinical outcomes are not necessarily determined specifically by these agents. Despite these limitations, we consider the published case reports to be worthy of consideration.

In a case series of four patients with life-threatening dabigatran-related bleeding (subdural haematoma, intracerebral haemorrhage, surgery for insertion of a pacemaker and gastrointestinal bleeding), the administration of aPCC (dose range 42-100 U/kg) was associated with bleeding being brought under control [61]. A number of other case reports have also reported successful outcomes following treatment with PCC or aPCC as a response to ischaemic stroke (embolic thrombus of the left middle cerebral artery) [46] or gastrointestinal bleeding $[23,32,62]$ occurring in patients under dabigatran treatment. However, in some of these cases rFVIIa was administered as concomitant therapy, making the specific impact of $\mathrm{PCC} / \mathrm{aPCC}$ on dabigatran anticoagulation difficult to estimate. In contrast, there have also been cases where the use of PCC alongside rFVIIa has appeared ineffective, with no improvement of coagulation parameters or reduction of bleeding [63].

\section{Safety of PCCs and aPCCs}

The procoagulant/prothrombotic risks of treatment with PCCs and aPCCs must be weighed against the benefits. It should be noted that neither PCCs nor aPCCs are currently licensed for the treatment of DOAC-induced anticoagulation; therefore, any such use is off-label. The majority of evidence relating to the safety of PCCs has been obtained from VKA reversal or non-anticoagulated patients with perioperative bleeding. These are very different situations from the emergency treatment of DOAC-induced anticoagulation, and more evidence is needed regarding the safety of PCCs in this setting.

Historically, PCCs/aPCCs have been associated with a risk of thrombotic complications when used for the treatment of haemophilia or VKA reversal [64]. Composition adjustments, such as the inclusion of coagulation inhibitors, reduced use of activated factors and improved balance of coagulation factor content, have been implemented with the aim of improving the safety of PCCs [65]. Relative levels of factor II (prothrombin) and the key inhibitor antithrombin have been identified as the major cause of thrombogenicity [66]. In an observational study in trauma patients, PCC was shown to increase the ETP for 3-4 days following treatment (i.e. approximately the half-life of prothrombin) [67]. In addition, patients receiving PCC had low levels of antithrombin. It has been suggested that PCCs should be labelled according to 
prothrombin content, rather than factor IX content [66]. Overall, the available safety data indicate that there are possible risks when using PCCs.

An in-vivo animal study assessed the safety of PCC for the treatment of dabigatran-induced anticoagulation [56]. In the absence of dabigatran, high-dose PCC (300 IU/kg) produced low-grade pulmonary emboli in 5/5 (100\%) of animals. However, when the same dose of PCC was administered to animals previously treated with dabigatran, the frequency of pulmonary emboli was decreased in the presence of dabigatran in a dose-dependent manner $(2 / 5$ (40 \%) at a dabigatran dose of $75 \mu \mathrm{g} / \mathrm{kg}, 1 / 5(20 \%)$ at $200 \mu \mathrm{g} / \mathrm{kg}$ and $0 / 5(0 \%)$ at $450 \mu \mathrm{g} / \mathrm{kg})$ [56].

In a porcine model of coagulopathy with blunt liver injury and no anticoagulation, administration of a four-factor PCC (50 IU/ $\mathrm{kg}$ ) resulted in protracted elevation of thrombin-antithrombin complexes and D-dimers, and formation of thromboemboli and pulmonary fibrinogen deposits in some animals [68]. Signs of disseminated intravascular coagulation were also shown in $44 \%$ of animals. In contrast, a PCC dose of $35 \mathrm{IU} / \mathrm{kg}$ safely improved coagulation parameters and halted blood loss. Furthermore, survival and total blood loss were significantly improved in both PCC groups when compared with control animals [68].

In contrast to the previous study, the administration of PCCs or aPCCs to pigs after blunt liver injury under high-dose dabigatran appears not to be associated with thromboembolic events. Histopathological assessments showed that there was no thrombus formation in the heart, lungs, liver and kidneys after administration of PCC $(25,50$ or $100 \mathrm{IU} / \mathrm{kg}$ ) [58] or aPCC (25 or $50 \mathrm{IU} / \mathrm{kg}$ ) [57].

\section{Clinical perspective and conclusion}

DOACs such as dabigatran have proven effective in decreasing the risk of ischaemic stroke in patients with AF, and in the prevention and long-term treatment of VTE. Although the bleeding risk associated with dabigatran is low, any anticoagulant can cause bleeding. With lifethreatening bleeding in dabigatran-treated patients, urgent reversal of the thrombin inhibitory effects of dabigatran should be considered. The available data indicate that PCCs and aPCCs may be able to reverse dabigatraninduced anticoagulation in a dose-dependent manner. However, we do not have high-level evidence to support the use of PCCs/aPCCs in this setting, so the recommendation to use them is based on haematological principles, animal studies, healthy volunteer studies, an ex-vivo study of 'real-world' patients, and outcomes in a few case reports.

Treatment with PCCs or aPCCs increases the concentrations of several coagulation factors, including prothrombin which has a half-life of 60-72 hours [51]. Thrombin generation may therefore be enhanced for several days after the use of PCCs to treat major bleeding [67]. This may be associated with an increased risk of thromboembolic events. The lack of high-level evidence with PCCs and aPCCs for dabigatran reversal makes it difficult to make dose recommendations, but it appears necessary to use the minimum effective dose. On the other hand, there is evidence that low doses may not be effective in reversing the anticoagulant effects of dabigatran, probably because of the need to increase the plasma concentration of thrombin to that of dabigatran [58]. This scenario is complicated by the lack of specific coagulation tests that are routinely available and rapid to perform, with established sensitivity and specificity for guiding the required dose of $\mathrm{PCC}$ or aPCC and then monitoring the effects of treatment. There is a clear need for a test that fulfils these criteria. Against this background, it is unsurprising that there are variations between guidelines for the use of PCCs/aPCCs in the management of bleeding among dabigatran-treated patients. Treatment decisions will be made on a case-by-case basis according to clinical judgement, local hospital protocols and product availability. Because of the theoretical thromboembolic risk, it is reasonable to titrate $\mathrm{PCCs} / \mathrm{aPCCs}$ according to the clinical condition of the patient, starting with an initial dose of $25 \mathrm{IU} / \mathrm{kg}$. However, clinical data are needed to establish the optimum dosing strategy. Because the mechanisms of action of PCCs and aPCCs are similar (both act by increasing thrombin generation), there is no need to use first one and then the other in a step-wise approach to bleeding management. It is essential to remember that the anticoagulant effect of dabigatran may be only one aspect contributing to coagulopathy; the likelihood of coexistent hyperfibrinolysis, dilutional coagulopathy and loss of coagulation factors, etc. [69] require a multi-therapeutic approach. In the future, once the specific reversal agent idarucizumab becomes widely available, this treatment will be considered preferable to PCCs and aPCCs for dabigatran reversal because it has not been associated with a risk of thromboembolic events and has shown no procoagulant effect in various laboratory analyses. The phase III RE-VERSE AD study of idarucizumab showed complete reversal of the anticoagulant effect of dabigatran within minutes, in patients with serious bleeding or who required an urgent procedure [19]. However, idarucizumab may not be available at every hospital for quite some time. Also, there could conceivably be clinical circumstances under which PCCs or aPCCs might be valuable as part of multimodal therapy, such as when thrombin generation is impaired as a result of trauma-induced coagulopathy [70], although this needs to be evaluated in clinical studies.

\section{Conclusions}

Certainly at present, PCCs and aPCCs are far more widely available than idarucizumab, meaning that their use for emergency reversal of dabigatran among bleeding patients may be warranted. The available data do not 
provide evidence that either PCCs or aPCCs should be considered preferable to the other. RCTs are required to provide a robust evidence base, to ascertain the optimum dosing strategy and to determine the relative effectiveness of PCCs and aPCCs in this setting.

\section{Abbreviations}

ACT: activated clotting time; AF: atrial fibrillation; aPCC: activated prothrombin complex concentrate; aPTT: activated partial thromboplastin time; CAT: calibrated automated thrombogram; CFT: clot formation time; $\mathrm{CT}$ : clotting time; DOAC: direct oral anticoagulant; dTT: diluted thrombin time; DVT: deep vein thrombosis; ECA: ecarin chromogenic assay; ECT: ecarin clotting time; ETP: endogenous thrombin potential; INR: international normalised ratio; PCC: prothrombin complex concentrate; PT: prothrombin time; RCT: randomised controlled trial; rFVlla: recombinant activated factor VII; r-TEG: Rapid TEG; TT: thrombin time; VKA: vitamin K antagonist; VTE: venous thromboembolism.

\section{Competing interests}

OG has received research funding from Novo Nordisk, Biotest, CSL Behring and Nycomed; he has also received honoraria for consultancy and/or travel support from CSL Behring, Boehringer Ingelheim, Bayer Healthcare and Portola. JA has received honoraria for consultancy from Boehringer Ingelheim and Portola. RB serves as a consultant, researcher, and speaker for Boehringer Ingelheim and Medtronic, and has served in those roles in the past for Pfizer/Bristol Myers and Daiichi-Sankyo. PG has received honoraria for serving as a speaker and providing consultancy for Boehringer Ingelheim, Pfizer/Bristol Myers, Daiichi-Sankyo, Bayer and AstraZeneca. MVH has received research funding from GSK, Actelion and Boehringer Ingelheim, and is on a steering committee for Boehringer Ingelheim. DGJ has received honoraria for consultancy from Boehringer Ingelheim, Bayer and Merck. JHL is on Steering Committees for Boehringer Ingelheim, CSL Behring, Grifols, Janssen and The Medicines Company. CVP has received honoraria for consultancy from Boehringer Ingelheim, Daiichi-Sankyo, Janssen and BMS-Pfizer. ACS has received research funding from Jannsen, and has received honoraria for consultancy from Boehringer Ingelheim, Daiichi-Sankyo, Bayer, Jansen, Portola and BMS-Pfizer. TS has received a research grant from Octapharma, consultancy fees from Daiichi-Sankyo, and speaker honoraria and consultancy fees from Bayer, Boehringer Ingelheim and BMS-Pfizer. GJdZ serves as a consultant or on advisory boards for Boehringer Ingelheim, Daiichi-Sankyo, Novartis and Remedy; he has also received funding for fundamental research projects from the National Institutes of Health, Boehringer Ingelheim and Novartis. JE has received honoraria and research support from Bayer, Boehringer Ingelheim, BMS, Daiichi-Sankyo, GSK, Janssen and Pfizer.

\section{Authors' contributions}

OG conceived of this article and wrote the manuscript. All authors contributed to drafting and editing the manuscript, and all authors approved the final version.

\section{Acknowledgements}

Final-stage editing of this manuscript was undertaken by Meridian HealthComms, funded by Boehringer Ingelheim.

\section{Author details}

'Department of Anesthesiology, RWTH Aachen University Hospital, Pauwelsstrasse 30, 52074 Aachen, Germany. ${ }^{2}$ The Icahn School of Medicine at Mount Sinai, New York, NY, USA. ${ }^{3}$ Northwestern University Feinberg School of Medicine, Chicago, IL, USA. ${ }^{4}$ Emergency Department and SAMU, Lille University Hospital, Lille, France. ${ }^{5}$ Department of Thrombosis and Hemostasis, Leiden University Medical Center, Leiden, The Netherlands. ${ }^{6}$ Department of Neurology, Weill Cornell Medical College, New York, NY, USA. ${ }^{7}$ Department of Anesthesiology, Duke University School of Medicine, Durham, NC, USA. ${ }^{8}$ Department of Emergency Medicine, Thomas Jefferson University, Philadelphia, PA, USA. ${ }^{9}$ Hofstra North Shore/LIJ School of Medicine, Lenox Hill Hospital, New York, NY, USA. ${ }^{10}$ University of Heidelberg, Heidelberg, Germany. ${ }^{11}$ Departments of Medicine and Neurology, University of Washington, Seattle, WA, USA. ${ }^{12}$ McMaster University, Hamilton, Ontario, Canada.

Published online: 28 April 2016

\section{References}

1. Gomez-Outes A, Suarez-Gea ML, Calvo-Rojas G, Lecumberri R, Rocha E, Pozo-Hernandez C, et al. Discovery of anticoagulant drugs: a historical perspective. Curr Drug Discov Technol. 2012;9:83-104.

2. Hylek EM, Evans-Molina C, Shea C, Henault LE, Regan S. Major hemorrhage and tolerability of warfarin in the first year of therapy among elderly patients with atrial fibrillation. Circulation. 2007;115:2689-96.

3. Fang MC, Go AS, Chang Y, Borowsky LH, Pomernacki NK, Udaltsova N, et al. Warfarin discontinuation after starting warfarin for atrial fibrillation. Circ Cardiovasc Qual Outcomes. 2010;3:624-31.

4. Eriksson Bl, Quinlan DJ, Weitz Jl. Comparative pharmacodynamics and pharmacokinetics of oral direct thrombin and factor Xa inhibitors in development. Clin Pharmacokinet. 2009;48:1-22

5. Connolly SJ, Ezekowitz MD, Yusuf S, Eikelboom J, Oldgren J, Parekh A, et al. Dabigatran versus warfarin in patients with atrial fibrillation. N Engl J Med. 2009;361:1139-51

6. Eikelboom JW, Wallentin L, Connolly SJ, Ezekowitz M, Healey JS, Oldgren J, et al. Risk of bleeding with 2 doses of dabigatran compared with warfarin in older and younger patients with atrial fibrillation: an analysis of the randomized evaluation of long-term anticoagulant therapy (RE-LY) trial. Circulation. 2011:123:2363-72.

7. Connolly SJ, Wallentin L, Ezekowitz MD, Eikelboom J, Oldgren J, Reilly PA, et al. The Long-Term Multicenter Observational Study of Dabigatran Treatment in Patients With Atrial Fibrillation (RELY-ABLE) study. Circulation. 2013;128:237-43.

8. Tamayo S, Frank Peacock W, Patel M, Sicignano N, Hopf KP, Fields LE, et al. Characterizing major bleeding in patients with nonvalvular atrial fibrillation: a pharmacovigilance study of 27467 patients taking rivaroxaban. Clin Cardiol. 2015;38:63-8.

9. Southworth MR, Reichman ME, Unger EF. Dabigatran and postmarketing reports of bleeding. N Engl J Med. 2013;368:1272-4.

10. Hernandez I, Baik SH, Pinera A, Zhang Y. Risk of bleeding with dabigatran in atrial fibrillation. JAMA Intern Med. 2015;175:18-24.

11. Stangier J, Clemens A. Pharmacology, pharmacokinetics, and pharmacodynamics of dabigatran etexilate, an oral direct thrombin inhibitor. Clin Appl Thromb Hemost. 2009;15 Suppl 1:9S-16S.

12. Vilchez JA, Gallego P, Lip GY. Safety of new oral anticoagulant drugs: a perspective. Ther Adv Drug Saf. 2014;5:8-20.

13. Poulsen BK, Grove EL, Husted SE. New oral anticoagulants: a review of the literature with particular emphasis on patients with impaired renal function. Drugs. 2012;72:1739-53.

14. Pradaxa prescribing information. http://bidocs.boehringer-ingelheim.com/ BIWebAccess/NiewServlet.ser?docBase=renetnt\&folderPath=/Prescribing\%20 Information/PIs/Pradaxa/Pradaxa.pdf. Accessed 19 Oct 2015.

15. European Medicines Agency. Pradaxa $110 \mathrm{mg}$ hard capsules summary of product characteristics. https://www.medicines.org.uk/emc/medicine/20760/ SPC/Pradaxa+110+mg+hard+capsules/. Accessed 19 Oct 2015.

16. Huttner HB, Schellinger PD, Hartmann M, Kohrmann M, Juettler E, Wikner J, et al. Hematoma growth and outcome in treated neurocritical care patients with intracerebral hemorrhage related to oral anticoagulant therapy: comparison of acute treatment strategies using vitamin $\mathrm{K}$, fresh frozen plasma, and prothrombin complex concentrates. Stroke. 2006;37:1465-70.

17. Grottke $\mathrm{O}$, Honickel M, van Ryn J, ten Cate H, Rossaint R, Spronk HMH. Idarucizumab, a specific dabigatran reversal agent, reduces blood loss in a porcine model of trauma with dabigatran anticoagulation. J Am Coll Cardiol. 2015;66:1518-9.

18. Honickel M, Treutler S, Van Ryn J, Tillmann S, Rossaint R, Grottke O. Reversal of dabigatran anticoagulation ex-vivo: porcine study comparing prothrombin complex concentrates and idarucizumab. Thromb Haemost. 2015;113:728-40.

19. Pollack Jr CV, Reilly PA, Eikelboom J, Glund S, Verhamme P, Bernstein RA, et al. Idarucizumab for dabigatran reversal. N Engl J Med. 2015;373:511-20.

20. Levy JH, Faraoni D, Spring JL, Douketis JD, Samama CM. Managing new oral anticoagulants in the perioperative and intensive care unit setting. Anesthesiology. 2013;118:1466-74.

21. Siegal DM, Cuker A. Reversal of novel oral anticoagulants in patients with major bleeding. J Thromb Thrombolysis. 2013;35:391-8.

22. Steiner T, Bohm M, Dichgans M, Diener HC, Ell C, Endres M, et al. Recommendations for the emergency management of complications associated with the new direct oral anticoagulants (DOACs), apixaban, dabigatran and rivaroxaban. Clin Res Cardiol. 2013;102:399-412. 
23. Dumkow LE, Voss JR, Peters M, Jennings DL. Reversal of dabigatran-induced bleeding with a prothrombin complex concentrate and fresh frozen plasma. Am J Health Syst Pharm. 2012;69:1646-50.

24. Carter A, Sarda P, George M, Corbett S. Hip arthroplasty fatality related to dabigatran induced gastrointestinal haemorrhage. Ann R Coll Surg Engl. 2014:96:115E-7E.

25. Hankey GJ, Eikelboom JW. Dabigatran etexilate: a new oral thrombin inhibitor. Circulation. 2011;123:1436-50.

26. Spinler S. The pharmacology and therapeutic use of dabigatran etexilate. J Clin Pharmacol. 2013;53:1-13.

27. Adams RL, Bird RJ. Review article: Coagulation cascade and therapeutics update: relevance to nephrology. Part 1: overview of coagulation, thrombophilias and history of anticoagulants. Nephrology (Carlton). 2009;14:462-70

28. Kozek-Langenecker SA, Afshari A, Albaladejo P, Santullano CA, De Robertis E, Filipescu DC, et al. Management of severe perioperative bleeding: guidelines from the European Society of Anaesthesiology. Eur J Anaesthesiol. 2013;30:270-382

29. Faraoni D, Levy JH, Albaladejo P, Samama CM. Groupe d'Intérêt en Hémostase Périopératoire. Updates in the perioperative and emergency management of non-vitamin K antagonist oral anticoagulants Crit Care. 2015;19:203.

30. Heidbuchel H, Verhamme $P$, Alings M, Antz M, Diener HC, Hacke W, et al. Updated European Heart Rhythm Association Practical Guide on the use of non-vitamin $\mathrm{K}$ antagonist anticoagulants in patients with non-valvular atrial fibrillation. Europace. 2015;17:1467-507.

31. van Ryn J, Stangier J, Haertter S, Liesenfeld KH, Wienen W, Feuring M, et al Dabigatran etexilate-a novel, reversible, oral direct thrombin inhibitor: interpretation of coagulation assays and reversal of anticoagulant activity. Thromb Haemost. 2010;103:1116-27.

32. Weitz JI, Quinlan DJ, Eikelboom JW. Periprocedural management and approach to bleeding in patients taking dabigatran. Circulation. 2012;126:2428-32.

33. Dager WE. Developing a management plan for oral anticoagulant reversal. Am J Health Syst Pharm. 2013;70:S21-31.

34. Bundgaard-Nielsen $\mathrm{M}$, Secher $\mathrm{NH}$, Kehlet H. 'Liberal' vs. 'restrictive' perioperative fluid therapy-a critical assessment of the evidence. Acta Anaesthesiol Scand. 2009;53:843-51.

35. Corcoran T, Rhodes JE, Clarke S, Myles PS, Ho KM. Perioperative fluid management strategies in major surgery: a stratified meta-analysis. Anesth Analg. 2012;114:640-51.

36. Boland MR, Noorani A, Varty K, Coffey JC, Agha R, Walsh SR. Perioperative fluid restriction in major abdominal surgery: systematic review and metaanalysis of randomized, clinical trials. World J Surg. 2013;37:1193-202.

37. Frith D, Davenport R, Brohi K. Acute traumatic coagulopathy. Curr Opin Anaesthesiol. 2012;25:229-34.

38. Grottke O, Fries D, Nascimento B. Perioperatively acquired disorders of coagulation. Curr Opin Anaesthesiol. 2015;28:113-22.

39. Fawole A, Daw HA, Crowther MA. Practical management of bleeding due to the anticoagulants dabigatran, rivaroxaban, and apixaban. Cleve Clin J Med. 2013:80:443-51.

40. van Ryn J, Grottke O, Spronk H. Measurement of dabigatran in standardly used clinical assays, whole blood viscoelastic coagulation, and thrombin generation assays. Clin Lab Med. 2014;34:479-501.

41. Hawes EM, Deal AM, Funk-Adcock D, Gosselin R, Jeanneret C, Cook AM, et al. Performance of coagulation tests in patients on therapeutic doses of dabigatran: a cross-sectional pharmacodynamic study based on peak and trough plasma levels. J Thromb Haemost. 2013;11:1493-502.

42. Stangier J, Stahle H, Rathgen K, Fuhr R. Pharmacokinetics and pharmacodynamics of the direct oral thrombin inhibitor dabigatran in healthy elderly subjects. Clin Pharmacokinet. 2008;47:47-59.

43. Dager WE, Gosselin RC, Kitchen S, Dwyre D. Dabigatran effects on the international normalized ratio, activated partial thromboplastin time, thrombin time, and fibrinogen: a multicenter, in vitro study. Ann Pharmacother. 2012;46:1627-36.

44. Alikhan R, Rayment R, Keeling D, Baglin T, Benson G, Green L, et al. The acute management of haemorrhage, surgery and overdose in patients receiving dabigatran. Emerg Med J. 2014;31:163-8.

45. Curvers J, van de Kerkhof D, Stroobants AK, van den Dool EJ, Scharnhorst V. Measuring direct thrombin inhibitors with routine and dedicated coagulation assays: which assay is helpful? Am J Clin Pathol. 2012;138:551-8.
46. Javedani PP, Horowitz BZ, Clark WM, Lutsep HL. Dabigatran etexilate: management in acute ischemic stroke. Am J Crit Care. 2013:22:169-76.

47. Dinkelaar J, Patiwael S, Harenberg J, Leyte A, Brinkman HJ. Global coagulation tests: their applicability for measuring direct factor Xa- and thrombin inhibition and reversal of anticoagulation by prothrombin complex concentrate. Clin Chem Lab Med. 2014:52:1615-23.

48. Herrmann R, Thom J, Wood A, Phillips M, Muhammad S, Baker R. Thrombin generation using the calibrated automated thrombinoscope to assess reversibility of dabigatran and rivaroxaban. Thromb Haemost. 2014;111:989-95.

49. Grottke O, van Ryn J, Spronk HM, Rossaint R. Prothrombin complex concentrates and a specific antidote to dabigatran are effective ex-vivo in reversing the effects of dabigatran in an anticoagulation/liver trauma experimental model. Crit Care. 2014;18:R27.

50. Cotton BA, McCarthy JJ, Holcomb JB. Acutely injured patients on dabigatran. N Engl J Med. 2011:365:2039-40.

51. Grottke $\mathrm{O}$, Levy JH. Prothrombin complex concentrates in trauma and perioperative bleeding. Anesthesiology. 2015;122:923-31.

52. Holland L, Warkentin TE, Refaai M, Crowther MA, Johnston MA, Sarode R. Suboptimal effect of a three-factor prothrombin complex concentrate (Profilnine-SD) in correcting supratherapeutic international normalized ratio due to warfarin overdose. Transfusion. 2009:49:1171-7.

53. Quinlan DJ, Eikelboom JW, Weitz JI. Four-factor prothrombin complex concentrate for urgent reversal of vitamin $\mathrm{K}$ antagonists in patients with major bleeding. Circulation. 2013;128:1179-81.

54. Zhou W, Schwarting S, Illanes S, Liesz A, Middelhoff M, Zorn M, et al. Hemostatic therapy in experimental intracerebral hemorrhage associated with the direct thrombin inhibitor dabigatran. Stroke. 2011;42:3594-9.

55. Pragst I, Zeitler SH, Doerr B, Kaspereit FJ, Herzog E, Dickneite G, et al. Reversal of dabigatran anticoagulation by prothrombin complex concentrate (Beriplex P/N) in a rabbit model. J Thromb Haemost. 2012:10:1841-8.

56. Herzog E, Kaspereit FJ, Krege W, Doerr B, van Ryn J, Dickneite G, et al. Thrombotic safety of prothrombin complex concentrate (Beriplex P/N) for dabigatran reversal in a rabbit model. Thromb Res. 2014;134:729-36.

57. Honickel M, Maron B, van Ryn J, Braunschweig T, ten Cate H, Spronk HMH et al. Therapy with activated prothrombin complex concentrate is effective in reducing dabigatran-associated blood loss in a porcine polytrauma model. Thromb Haemost. 2016;115:271-84.

58. Honickel M, Braunschweig T, Van Ryn J, Ten Cate H, Spronk H, Rossaint R, et al. Prothrombin complex concentrate is effective in treating the anticoagulant effects of dabigatran in a porcine polytrauma model. Anesthesiology. 2015;123:1350-61.

59. Eerenberg ES, Kamphuisen PW, Sijpkens MK, Meijers JC, Buller HR, Levi M. Reversal of rivaroxaban and dabigatran by prothrombin complex concentrate: a randomized, placebo-controlled, crossover study in healthy subjects. Circulation. 2011;124:1573-9.

60. Marlu R, Hodaj E, Paris A, Albaladejo P, Cracowski JL, Pernod G. Effect of non-specific reversal agents on anticoagulant activity of dabigatran and rivaroxaban: a randomised crossover ex vivo study in healthy volunteers. Thromb Haemost. 2012;108:217-24.

61. Schulman S, Ritchie B, Goy JK, Nahirniak S, Almutawa M, Ghanny S. Activated prothrombin complex concentrate for dabigatran-associated bleeding. Br J Haematol. 2014;164:308-10.

62. Masotti L, Lorenzini G, Seravalle C, Panigada G, Landini G, Cappelli R, et al. Management of new oral anticoagulants related life threatening or major bleedings in real life: a brief report. J Thromb Thrombolysis. 2015:39:427-33.

63. Lillo-Le Louet A, Wolf M, Soufir L, Galbois A, Dumenil AS, Offenstadt G, et al. Life-threatening bleeding in four patients with an unusual excessive response to dabigatran: implications for emergency surgery and resuscitation. Thromb Haemost. 2012;108:583-5.

64. Levy JH, Tanaka KA, Dietrich W. Perioperative hemostatic management of patients treated with vitamin $\mathrm{K}$ antagonists. Anesthesiology. 2008:109:918-26.

65. Franchini M, Lippi G. Prothrombin complex concentrates: an update. Blood Transfus. 2010:8:149-54.

66. Dusel CH, Grundmann C, Eich S, Seitz R, Konig H. Identification of prothrombin as a major thrombogenic agent in prothrombin complex concentrates. Blood Coagul Fibrinolysis. 2004;15:405-11.

67. Schochl H, Voelckel W, Maegele M, Kirchmair L, Schlimp CJ. Endogenous thrombin potential following hemostatic therapy with 4-factor prothrombin complex concentrate: a 7-day observational study of trauma patients. Crit Care. 2014;18:R147. 
68. Grottke O, Braunschweig T, Spronk HM, Esch S, Rieg AD, van Oerle R, et al. Increasing concentrations of prothrombin complex concentrate induce disseminated intravascular coagulation in a pig model of coagulopathy with blunt liver injury. Blood. 2011;118:1943-51.

69. Hess JR, Brohi K, Dutton RP, Hauser CJ, Holcomb JB, Kluger Y, et al. The coagulopathy of trauma: a review of mechanisms. J Trauma. 2008:65:748-54

70. Harr JN, Moore EE, Wohlauer MV, Droz N, Fragoso M, Banerjee A, et al. The acute coagulopathy of trauma is due to impaired initial thrombin generation but not clot formation or clot strength. J Surg Res. 2011;170:319-24. 